\title{
Household-level transition methodology towards sustainable material footprints
}

Originally published in:

Journal of cleaner production, 132 (2016), 184-191

DOI: 10.1016/j.jclepro.2015.03.009 


\section{Household-level transition \\ methodology towards sustainable material footprints}

a University of Helsinki, Department of Environmental Sciences, Helsinki, Finland

b Aalto University, Department of Design, Helsinki, Finland

c Wuppertal Institute for Climate, Environment and Energy, Wuppertal, Germany

d ITMO University, Institute of Refrigerating and Biotechnology, St. Petersburg, Russia

* Corresponding author:

Senja Laakso

University of Helsinki

Department of Environmental Sciences

P.O. Box 65

Viikinkaari 2a

ooo14 Helsinki

Finland

E-mail: senja.laakso@helsinki.fi

Phone: +358 50-4480940

* Corresponding author:

Michael Lettenmeier

Wuppertal Institute for Climate, Environment and Energy

Döppersberg 19

42103 Wuppertal

E-mail: michael.lettenmeier@wupperinst.org

This is the author's version of a work that was accepted for publication. Changes resulting from the publishing process, such as editing, corrections and structural formatting, may not be reflected in this document. Changes may have been made to this work since it was submitted for publication. A definitive version was subsequently published in the Journal cited above. 


\title{
Household-level transition methodology towards sustainable material footprints
}

Senja Laakso ${ }^{\text {a }}$

Michael Lettenmeier ${ }^{\text {b,c,d }}$

${ }^{a}$ University of Helsinki, Dep. of Environmental Sciences, P.O. Box 65 (Viikinkaari 2a) 00014

University of Helsinki, Finland. E-mail: senja.laakso@helsinki.fi

${ }^{\mathrm{b}}$ Aalto University, Dep. of Design, Hämeentie 135 C, 00760 Helsinki, Finland

${ }^{c}$ Wuppertal Institute for Climate, Environment and Energy, Döppersberg 19, 42103 Wuppertal, Germany. E-mail: michael.lettenmeier@wupperinst.org

d ITMO University, Institute of Refrigerating and Biotechnology, Lomonosova ulitsa, 9, St. Petersburg, Russia, 191002

Corresponding author: Senja Laakso (senja.laakso@helsinki.fi, +358 50448 0940)

\section{Highlights}

- A new methodology for studying sustainability transition at household level

- The methodology covers assessment, vision development, experiments and upscaling

- Measuring and reducing material footprints according to the MIPS concept

- Households developed their own roadmaps towards sustainable resource use

- Relevant experiments were tested and future services simulated

\begin{abstract}
This paper presents a new household-level methodology for transition towards sustainability. The methodology includes measuring the resource use of households on a micro level, testing relevant measures towards a one-planet resource use, and developing mainstreaming options in co-operation with households and providers of services, products, and infrastructures. We use the MIPS (Material Input Per unit of Service) method to calculate the use of natural resources and concentrate on the material footprint as an aggregated indicator for the overall use of material resources. With HST (Household-level Sustainability Transition) methodology, we extend the material footprint methodology from just measuring household resource use to developing visions, conducting experiments, as well as learning and upscaling, all of which contribute to the whole TransitionEnabling Cycle. Results from the first application of the HST methodology on five households in Jyväskylä, Finland, show that it is possible to achieve a significantly more sustainable level of consumption by a relatively few changes in everyday living. Achieving a one-planet use of material resources, however, also requires systemic changes.
\end{abstract}

\section{Keywords}

Material footprint; sustainability transition; dematerialization; household consumption 


\section{Introduction - reducing global resource use by local activities}

Material flows from nature into the human economy and back to nature have been steadily growing for decades, even for centuries (Krausmann et al. 2009). Already in the late 1960s, Ayres and Knees (1969) identified a connection between the volume of human resource use and the extent of environmental impacts. As a result of this growing use, resource availability has declined dramatically (e.g. Erdmann and Graedel, 2011; Halada et al. 2008; Lutz et al. 2012; Global Footprint Network, 2014; WWF, 2012). In addition, under business-as-usual conditions, the extraction and harvest of natural resources between 2000 and 2030 is expected to nearly double from 52 to over 100 billion tonnes (Giljum et al. 2009). These figures include the extraction of fossil fuels, metals, minerals, and biomass (used extraction), but not the excavation for infrastructures, mining and quarrying, nor the erosion linked to agriculture (unused extraction). Unused extraction ranges from double to triple the size of the used extraction (Bringezu, 2011), and this ratio is expected to grow (Aachener Stiftung, 2011).

Schmidt-Bleek (1993) has proposed a $90 \%$ reduction in material consumption in advanced economies by 2050 . This target, known as 'factor 10', derives from the assumption that global abiotic resource extraction should be halved and shared equitably by 10 billion people by 2050 , and it is supported by a number of scientific observations of how humans impact processes (Schmidt-Bleek, 1993). Industrialized countries should be forerunners in reducing their resource use because they have benefited from overexploitation of the Earth's resources, have developed presently unsustainable lifestyles, and are able to develop and provide new solutions in production and consumption (SchmidtBleek, 1993; 2009; United Nations, 1992).

To use natural resources sustainably, we must use fewer resources more efficiently from the household to the national level and in both the public and private sectors. The role of households in reducing resource use to a sustainable level is vital (Caeiro et al., 2012; Lorek and Spangenberg, 2001), since the way households live is an important driver of overconsumption of natural resources (Bringezu et al., 2009; Lettenmeier et al., 2014b). Attempts to encourage sustainable consumption have not advanced significantly and household consumption continues to grow (e.g. Hobson, 2003; Mont et al., 2014; Tukker et al., 2010). This failure is due mostly to simplistic behavioural assumptions that overlook the socio-cultural aspects of daily practices (Doyle and Davies, 2013; Heiskanen et al., 2013). To understand the opportunities for transitioning towards lower household resource use, we must 1) compare material intensities of products and services, 2) quantify and understand how household consumption forms and changes, and 3) generate and evaluate alternative configurations (e.g. Doyle and Davies, 2013; Schroeder, 2010).

Even if we can address most of the resource use in the human economy to the consumption of individual households at some point, households can directly influence their material consumption only partially (Kopsakangas-Savolainen and Juutinen, 2013; Lettenmeier et al., 2014a). Existing infrastructure and prevailing services determine a basic level of resource use that exceeds sustainability limits even among minimum income receivers in an industrialized country such as Finland (Hirvilammi et al., 2013). Systemic changes call for alterations in the overall configuration of these systems, including technology, policy, markets, infrastructure, cultural meaning and scientific knowledge, in addition to consumer practices and how they are carried out (Geels, 2011; Schneidewind and Augenstein, 2012). As Liedtke et al. (2013) and Schroeder (2010) point out, research and innovations 
on sustainability need dynamic links between micro-level implementations and macro-level strategies, and vice versa.

This paper aims to take into account both of these premises of household consumption: We develop a new step-by-step method that goes beyond the approaches that have been used so far in studying sustainable resource use on the household level. Earlier approaches have concentrated on assessing the resource use of household consumption (e.g. Kotakorpi et al., 2008; Lettenmeier et al., 2012) and developing general visions for sustainable resource use on household level (Lettenmeier et al., 2014b). The Household-level Sustainability Transition methodology, or HST, goes further by developing visions for sustainable resource use on the level of households. On the basis of this it continues by experimenting low-resource consumption in the households and adds a learning and upscaling process including relevant stakeholders. In other words, HST encompasses the whole framework for transition towards low-resource consumption as proposed by Schneidewind and Scheck (2012). Thus, it opens options for achieving action for an absolute reduction in natural resource use in reality and is not limited to just stating the need for absolute reduction and generating general visions.

This paper also reports on the first application of HST in practice and presents the main results from a project in Jyväskylä, Finland. We then analyse whether this kind of transition approach is useful in targeting significant reductions in resource use at the household level, what is the role scientific knowledge plays in this transition, and how we can upscale the lessons from this qualitative study to the local level.

Section 2 presents the principles of the MIPS (Material Input Per unit of Service) methodology, as well as the transition approach and its application in the absolute reduction of household resource use. We also look at previous studies on the material footprints of households. Section 3 introduces the materials and methods, and Section 4 presents the results of our research project. In conclusion, in Section 5 we evaluate the significance of this kind of methodology for studying and more generally promoting sustainable consumption and offer suggestions for further research and action.

\section{From household material flows to sustainability transitions}

As noted in the introduction, we need to quantify the material intensity of our consumption practices, understand how to change these practices, and overcome the barriers to more sustainable consumption. We must focus on the links between supply and demand, on micro- as well as on macro-level dimensions. In the following section, we present two approaches: the material footprint calculation and the Transition-Enabling Cycle. We use them in our study to take into account the different aspects of sustainable resource use.

\subsection{MIIPS method in quantifying the sustainable level of natural resource use}

To measure the system-wide environmental impacts of consumption, Schmidt-Bleek (1993) introduced the MIPS (Material Input Per unit of Service) concept. MIPS sums up the amount of natural material input (MI) required throughout the life cycle of a certain product or service in order to provide a specific benefit (called service, S). Material inputs are calculated separately for five resource categories: abiotic raw material, biotic raw material, soil movement in agriculture and forestry, air, and water (Ritthoff et al. 2002; Schmidt-Bleek et al. 1998) and then expressed in mass units such as 
kilograms. MI contains both the resources used in the human economy and the unused extraction (see Brinegzu et al. 2003; Stricks et al. 2014) .

Based on the MIPS concept, the material footprint sums up abiotic and biotic resources, as well as topsoil erosion in agriculture. Thus, the material footprint includes the same resource categories as the macroeconomic indicators TMC (total material consumption, or sum of household consumption, public consumption, and capital formation) and TMR (the total material requirement of all production and consumption activities) (Bringezu et al. 2003). Lettenmeier et al. (2009) propose using material footprint as a synonym for micro-level TMR (see also Ritthoff et al., 2002) ) in order to extend the footprint metaphor to the use of material resources. In this paper, we use the material footprint as a basis for quantifying household consumption.

Bringezu (2009) used national material flow calculations (e.g. Mäenpää 2005; Seppälä et al. 2011 for Finland) to concretize the sustainable level of material resources use to approximately ten tonnes of TMC per capita. Of this TMC, Lettenmeier et al. (2014b) suggested allocating $80 \%$, or eight tonnes, to households and $20 \%$ to public consumption, as public consumption (e.g. schools, universities, and defense activities) cannot be reasonably allocated to individual households. They constituted a preliminary proposal to allocate this benchmark of eight tonnes to different consumption components of nutrition ( 3 tonnes per person per year), housing (1.6 tonnes), mobility ( 2 tonnes) and other purposes (1.4 tonnes, respectively). This proposal is based on development of both consumption practices and technology that appears plausible on the basis of existing research results. However, Lettemeier et al. (2014b) stress that their proposition is only one possible example of allocating the eight tonnes to these consumption components and it could be distributed differently according to individual households' demands and desires.

\subsection{Transition-Enabling Cycle as a framework to sustainability transitions}

Transitions can be seen as non-linear processes resulting from interaction at three levels: niches, sociotechnical regimes, and the socio-technical landscape (for a multi-level perspective on transitions, see, e.g., Geels, 2002; 2011; Rip and Kemp, 1998; Schneidewind and Augenstein, 2012). The sociotechnical landscape is characterized by large-scale developments and trends, rising from political ideologies, societal values, and economic patterns. Representing a lower level, regime refers to the structure and culture of social groups. (Geels, 2011, 27.) Here, locked-in mechanisms and practices can change due to innovations from niches. Kemp et al. (1998) and Schot and Geels (2008) have observed that niche innovations occur when small groups of actors engage in new practices, based on expectations and visions. Individual and social learning processes are essential for new routines to become a part of regime (Shove and Walker, 2007).

The sustainability transition approach derives from the conclusion that the factor 10 target can only be realized through transitions at different scale-levels and in multiple dimensions, such as technological, material, institutional, politic, economic, and socio-cultural (Rotmans and Loorbach, 2010; Schneidewind and Scheck, 2012; Shove and Walker, 2007). Overcoming barriers to sustainability transition require not only long-term strategies, but also processes of individual and social learning, as well as experimenting with ways to achieve these targets. Engaging actors in the process and developing societal pressure enables emerging niches to create new societal regimes. (Loorbach and Rotmans, 2010.) 
Schneidewind and Scheck (2012) proposed a 'Transition-Enabling Cycle' for structuring transdisciplinary research on the German energy system's sustainability transition (fostering these transitions is also known as transition management; see, e.g., Rotmans et al. 2001). The TransitionEnabling Cycle consists of four successive fields: assessing the problem, developing a vision, implementing an experiment, and learning and upscaling (see Figure 1).

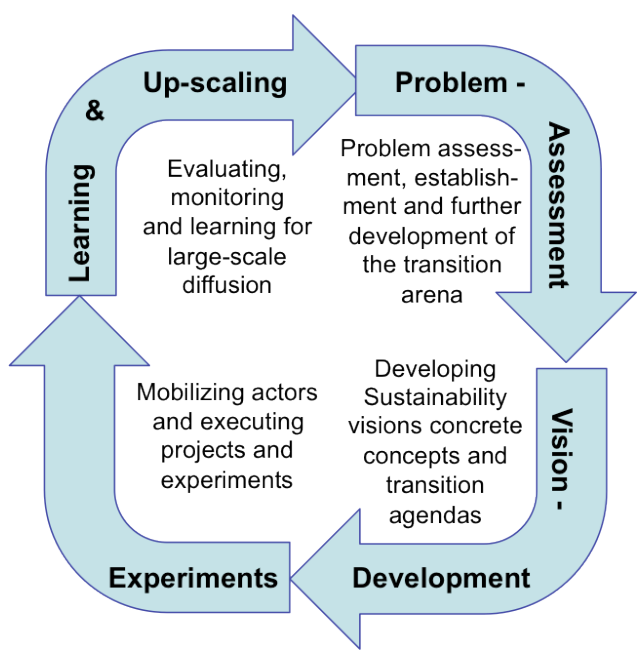

Figure 1. Transition-Enabling Cycle (Schneidewind and Scheck, 2012).

The HST methodology follows the steps for transition management proposed by Loorbach (2007) and Loorbach and Rotmans (2006; 2010): It 'stimulates niche development' at the micro level by establishing the transition arena by measuring household resource use. It develops a sustainability vision and derives pathways for actors to these visions. It then prepares transition experiments for specific pathways, as well as learning goals for these experiments. According to Rotmans and Loorbach (2009), empowering niches by providing resources, such as knowledge, competence, and space for experimenting, is one of the key elements in the transition process. Finally, it gives suggestions for upscaling these experiments. Throughout the process, we monitor and evaluate the transition management process (Rotmans and Loorbach, 2009). Before we describe the framework for the HST methodology in more detail, we present the conclusions of previous studies on household resource use. We do not intend to provide a literature overview, but instead to sum up the lessons learned from these studies and point out how we apply these lessons in our research. Hence, we focus mainly on Finnish and European studies with a focus on material footprint assessment.

\subsection{From problem assessment to vision development - lessons from previous studies}

Two micro-level projects have studied the material footprints of Finnish households. The 'FIN-MIPS Household' project studied the natural resource use of 27 households and a total of 78 members (Kotakorpi et al. 2008). Another study formed part of the project 'Back to basics: Consumption and basic income security' coordinated by the Social Insurance Institution of Finland. This study analyzed the material footprints of 18 single households living on basic social security (Hirvilammi et al. 2013; Laakso, 2011; Lettenmeier et al. 2012; Lettenmeier et al. 2014a). Of the 45 households examined in these studies, 44 exceeded the sustainable material footprint of eight tonnes by a factor of 1.5 to 15 . The households with the smallest material footprints were minimum-income receivers who were less able to meet their basic needs, yet still exceeded the level of sustainable natural resource use (Hirvilammi et al., 2013). 
In addition to the material footprint calculations, Kotakorpi et al. (2008) summed up the lowest results for each consumption category to quantify potentials for the absolute reduction of household resource use. They ended up at a 'factor 4 household' with a material footprint that was $25 \%$ of the average. They also quantified the reduction potential of one household and concluded that in the short term, this household could reduce its use of natural resources by $28 \%$. This result, in addition to the factor 4 household, has served as a benchmark in developing the sustainable material footprint of eight tonnes (Lettenmeier et al., 2014b). These results were also the first to propose that within the prevailing system, it could be possible to reduce consumption by a factor of four. Hirvilammi et al. (2013), however, found that sustainable consumption also requires systemic changes. In other words, Kotakorpi et al. (2008) and Hirvilammi et al. (2013) contributed to our knowledge of household resource use and showed the need of transition to sustainability. Enabling this transition, however, will require guidance and governance that introduce visions and goals for the change (Smith et al., 2005; Lettenmeier et al., 2014b).

When it comes to proceeding from studying the resource use of household consumption to the whole Transition-Enabling Cycle, the 'SPREAD Sustainable Lifestyles 2050' project took some additional steps beyond the studies presented above. As part of the project, four scenarios for sustainable lifestyles in 2050 were developed based on the prerequisite of attaining a material footprint of eight tonnes per capita per year (Leppänen et al., 2012; Neuvonen et al., 2014). The backcasting method served to describe how changes in societies emerge and transform, and how experiments can serve as bottom-up drivers for transitions (Lähteenoja et al., 2013). Another part of the SPREAD project investigated how to reduce in practice the material footprints of 60 persons from four European countries (Finland, Germany, Hungary, and Spain) (Kuittinen et al., 2013; Groezinger et al., 2013). Material footprint calculations and interviews served as a basis for developing the current and future lifestyle profiles of the participants (Kuittinen et al., 2013). A large diversity of lifestyles was identified between the participants and their material footprints, ranging from 8.5 to 69 tonnes per person per year (Groezinger et al., 2013).

Indicators, such as the material footprint, that identify the key issues and rate of success can serve as 'powerful pedagogical and communicative tools' for transition towards sustainability (Lyytimäki et al., 2013, 389). Because these indicators offer no specific guidelines to decision-making, we must use them together with other tools and methods (Caeiro et al., 2012). The experiences of the SPREAD project provide valuable information on scenario use and the backcasting method in studies of sustainable consumption, and other European studies have also employed similar methods (e.g. Doyle and Davies, 2013). Kersten et al. (2014) highlight the role of participatory methods, such as workshops. As Lähteenoja et al. $(2013,1)$ point out, however, a 'lot of imagination is needed to understand how the shift from the current overconsumption can be turned into sustainable lifestyles for all. On the one hand, we need a deeper understanding on how to scale up current promising practices. On the other hand, we need to know how far these practices will take us towards sustainable living for all.'

In this paper, we use the whole Transition-Enabling Cycle as a framework to develop the HST methodology step by step in order to facilitate niche innovations that lead to socio-technical transitions. The following section proceeds to the HST methodology, which aims both at overcoming the shortcomings of the previous studies presented in this section and at including all phases of the Transition-Enabling Cycle for enabling households to achieve an absolute reduction in resource use according to the MIPS concept. 


\section{Broadening the perspective to the Household-level Sustainability Transitions - data and methods}

Section 2.3 exposed the need to combine methods from different studies of household consumption into a coherent whole that takes into account the different phases of transition. Next, we propose a methodology for broadening the view on the material consumption of households to cover the entire Transition-Enabling Cycle of Schneidewind and Scheck (2012), as presented in Figure 1 in Section 2.2. The main steps of the methodology described here are: 1) assessing the problem by calculating material footprints for participating households, 2) developing household-specific visions in the form of roadmaps, 3) having participating households conduct experiments, and 4) learning and upscaling together with different stakeholders.

We applied the HST methodology the first time in Jyväskylä, Finland in 2014 in the 'Future Household' project coordinated by the Finnish Innovation Fund Sitra. The project began in April 2014 with a call for participating households. Five of the 40 households that applied were selected for the project. Due to the experimental and in-depth nature of the project, the number of households was limited to five. Moreover, testing this new and transdisciplinary approach first with a relatively small number of households seemed prudent.

The households included one single person (household A), one commune of two students (household B), two families with two and three children (households C and D), and one empty-nest couple (household E). Two of the households lived in the city center, one in a suburb and two in surrounding, smaller villages. In addition, the households varied greatly in terms of living space per person and car ownership. Due to the themes of the project (sustainability and resource-wisdom), we expected all households that applied to be at least somewhat interested in these issues. Kotakorpi et al. (2008), however, found no correlation between environmental consciousness and the material footprints of the households studied and this is in line with the results of other studies on the value-action-gap of consumption (e.g. Barr, 2006). When asked about their motivation to apply for the project, the households replied:

"I saw the announcement on Facebook. -- We both thought that this sounds really interesting." "We thought that, well, since we are students, we cannot afford to consume that much, but we haven't thought about these issues from an ecological perspective at all, so we were thinking that it would be interesting to find out how to make ecological choices with a small budget. -- But we haven't thought about any environmental issues previously; maybe this is a way to learn how to." (Household B)

We interviewed the households for the first time in June 2014. The in-depth interviews covered the themes of everyday routines, consumption practices, and environmental attitudes. The kick-off event took place in August 2014, followed immediately by a three-week period for the consumption survey. The long interval between the interviews and the kick-off was due to the timing of the survey period: to obtain results from everyday living, we wanted measurements from the working term instead of from the holidays. The households monitored the consumption components of housing and nutrition (first week); household goods and leisure time activities (second week); and daily mobility, tourism and (where applicable) summer houses (third week). Based on feedback from the households in a previous study (Kotakorpi et al., 2008), we halved the duration of the survey period. We calculated the material 
footprints for the different consumption components from the data obtained during the survey period. The interview data complemented the data from the monitoring.

A central part of the vision development was a workshop in which participants co-created ideas for reducing the material footprints of the households. The households received their material footprint results from the survey period in advance. The workshop applied backcasting so as to propose for each household a material footprint target for 2030 as a halfway point from the present to a sustainable level of eight tonnes per person per year by 2050 . The year 2030 served as a reference year for the workshop in order to keep changes more imaginable, as research (e.g., Lähteenoja et al., 2013) has identified the imagination of future lifestyles as a challenge. Assisted by the project team, the households developed ways to reduce their material footprints through both behavioral and systemic changes. On the basis of these ideas, each household created a roadmap detailing measures and pathways towards halving their material resource use. Previous studies (e.g., Kersten et al., 2014) have shown that such participatory methods are both valuable and empowering. The roadmaps served as the basis for the experimental part of the project. The material footprints and each household's target levels for 2030 appear in Figure 2 in Section 4.

The households chose some of the ideas in their roadmaps to be implemented in a four-week experiment period that began in October 2014. We estimated that four weeks would be sufficient time for people to establish themselves in the new routines and forget the temporary nature of the experiments or, as Spaargaren (1997, 28-29) describes, to de- and re-routinize. The experiments included notable changes such as giving up a car or switching to a vegan diet. In addition, simulated services such as car-sharing and improved public transportation were part of the experiments. A more detailed description of the experiments appears in Table 1.

Table 1. List of experiments conducted during the four-week period.

\begin{tabular}{|c|c|c|c|}
\hline $\begin{array}{l}\text { House- } \\
\text { hold }\end{array}$ & & Topic fields & Actual experiments \\
\hline $\mathrm{A}$ & Single & 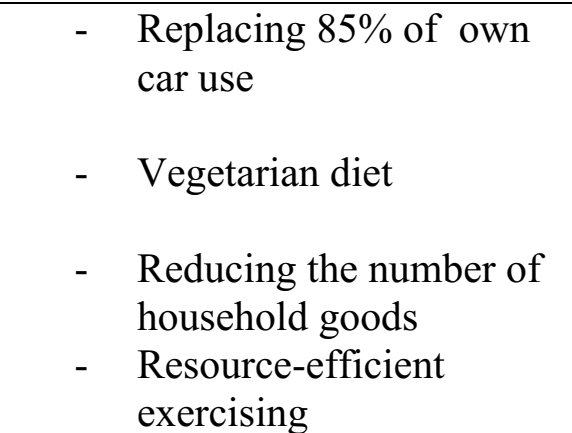 & $\begin{array}{l}\text { - Using public transport and car- } \\
\text { pooling, one remote working day per } \\
\text { two-week period } \\
\text { - } \begin{array}{l}\text { Having three or more vegetarian } \\
\text { days per week }\end{array} \\
\text { - } \quad \text { Replacing goods with services } \\
\text { - } \quad \begin{array}{l}\text { Reducing the need for infrastructure } \\
\text { in exercising }\end{array}\end{array}$ \\
\hline B & $\begin{array}{l}\text { Two } \\
\text { students }\end{array}$ & $\begin{array}{ll}\text { - } & \text { Giving up a car } \\
\text { - } & \text { Attention to energy use } \\
\text { - } & \text { Resource-efficient eating } \\
& \text { habits } \\
\text { - } & \text { Reducing waste }\end{array}$ & $\begin{array}{l}\text { - Using a shared car and car-pooling, } \\
\text { home-delivery of food twice a week } \\
\text { - } \quad \text { Conserving electricity and water } \\
\text { - } \quad \text { Increasing the share of vegetables in } \\
\text { daily diet } \\
\text { - } \quad \text { FiFo (first in, first out) concept } \\
\text { simulating a smart fridge, reducing } \\
\text { the amount of food waste and better } \\
\text { sorting of waste }\end{array}$ \\
\hline
\end{tabular}




\begin{tabular}{|c|c|c|c|}
\hline & & $\begin{array}{ll}- & \text { Reducing the number of } \\
\text { household goods }\end{array}$ & $\begin{array}{l}\text { - Replacing goods with services and } \\
\text { using recycling services }\end{array}$ \\
\hline $\mathrm{C}$ & $\begin{array}{l}\text { Family } \\
\text { with two } \\
\text { children }\end{array}$ & $\begin{array}{l}\text { - Using even less car than } \\
\text { before } \\
\text { - Attention to energy use } \\
\text { - Vegan diet }\end{array}$ & $\begin{array}{l}\text { - Using shared car if necessary instead } \\
\text { of borrowing one, home-delivery of } \\
\text { food once a week } \\
\text { - Energy consultancy to the new } \\
\text { home, reducing the need for extra } \\
\text { space with general-purpose space } \\
\text { design } \\
\text { - Changing to whole vegan diet and } \\
\text { using ingredients that are easily } \\
\text { available (food of the season) }\end{array}$ \\
\hline $\mathrm{D}$ & $\begin{array}{l}\text { Family } \\
\text { with } \\
\text { three } \\
\text { children }\end{array}$ & $\begin{array}{l}\text { - Attention to energy use } \\
\text { - } \quad \text { Vegetarian diet }\end{array}$ & $\begin{array}{l}\text { - Simulating improved public } \\
\text { transport, such as on-demand bus } \\
\text { service, as well as existing public } \\
\text { transport, car-pooling, and car- } \\
\text { sharing. One remote working day per } \\
\text { week for the other parent } \\
\text { - } \quad \text { Reducing the need for extra space } \\
\text { and making remote working possible } \\
\text { - } \quad \text { Replacing meat products with } \\
\text { vegetables at every second meal. }\end{array}$ \\
\hline $\mathrm{E}$ & $\begin{array}{l}\text { Empty- } \\
\text { nest } \\
\text { couple }\end{array}$ & $\begin{array}{ll}\text { - } & \text { Giving up second car } \\
\text { - } & \text { Smaller apartment } \\
\text { - } & \text { Vegetarian diet } \\
\text { - } & \text { Reducing the number of } \\
& \text { household goods }\end{array}$ & $\begin{array}{l}\text { - Using public transport. One person } \\
\text { works from home once a week } \\
\text { - Moving to a smaller apartment in the } \\
\text { city center, also reducing the need } \\
\text { for a car } \\
\text { - } \quad \text { Vegetarian meal once a day } \\
\text { - } \quad \text { Giving up extra clothes }\end{array}$ \\
\hline
\end{tabular}

In addition, the households had ideas that were not implemented during the experiment period but were meant to be carried out in the near future. These included changing to eco-electricity, using a lendable cargo bike instead of a car, using insects as food, making renovations on the basis of the energy consultant's suggestions, replacing material-intensive hobbies with more resource-efficient ones, and cultivating own vegetables, for instance.

During the experiments, we made calculations on their effects to the material footprints, as well as observations on how the experiments affected everyday practices of households. The households shared their experiences in social media and the regional newspaper throughout the project. This facilitated the connection between the different phases of the Transition-Enabling Cycle, as households reflected the influence of the experiments to their everyday living and reduction targets.

After the one-month period of experiments, the households and the project team, together with infrastructure providers, service providers and municipal servants, discussed the experiences and results from the project. In this 'future workshop', ways of overcoming the barriers for sustainable 
lifestyles were brainstormed to find out possibilities for mainstreaming sustainable solutions. The roles of consumers, and public and private sectors in reducing natural resource use of household consumption were also discussed. The workshop was linked to the development of a new residential area, Kangas, next to Jyväskylä city center. The new area is designed on the basis of the 'One Planet Living' principle and the workshop aimed at supporting this principle by utilizing the results of the project.

After the workshop, we interviewed eight 'gatekeepers' of which three were public service providers (gatekeepers 1, 2, and 3), two private service providers (gatekeepers 4 and 5) and three local policymakers (gatekeepers 6, 7, and 8), on their thoughts about the upscaling potential of the experiments. Four of these gatekeepers also participated in the workshop. In addition, we interviewed the households one last time after the final workshop. The content of these interviews was the course of the experiments and feedback on the whole project.

\section{Results from the first application of Household-level Sustainability Transition methodology}

The material footprints of the households varied from 20 to 69 tonnes per person per year (see Figure 2). The consumption components with most variation were everyday mobility, tourism, and housing. The high share of mobility in households D and E can be explained by the use of two cars in both households. Household $\mathrm{C}$, on the other hand, did not own a car, which can be seen as a clearly smaller material footprint of daily mobility. When it comes to housing, the size of the house or the apartment reflects to the material footprint of housing. Household B had the highest material footprint of tourism. This was mostly due to weekend trips to meet families and friends in other Finnish cities. The material footprints of nutrition were close to the average in all but one household (A) whose material footprint for nutrition was below half of average due to low-meat diet. Household B, on the other hand, had the highest material footprint of nutrition due to higher than average consumption of meat and dairy products. 


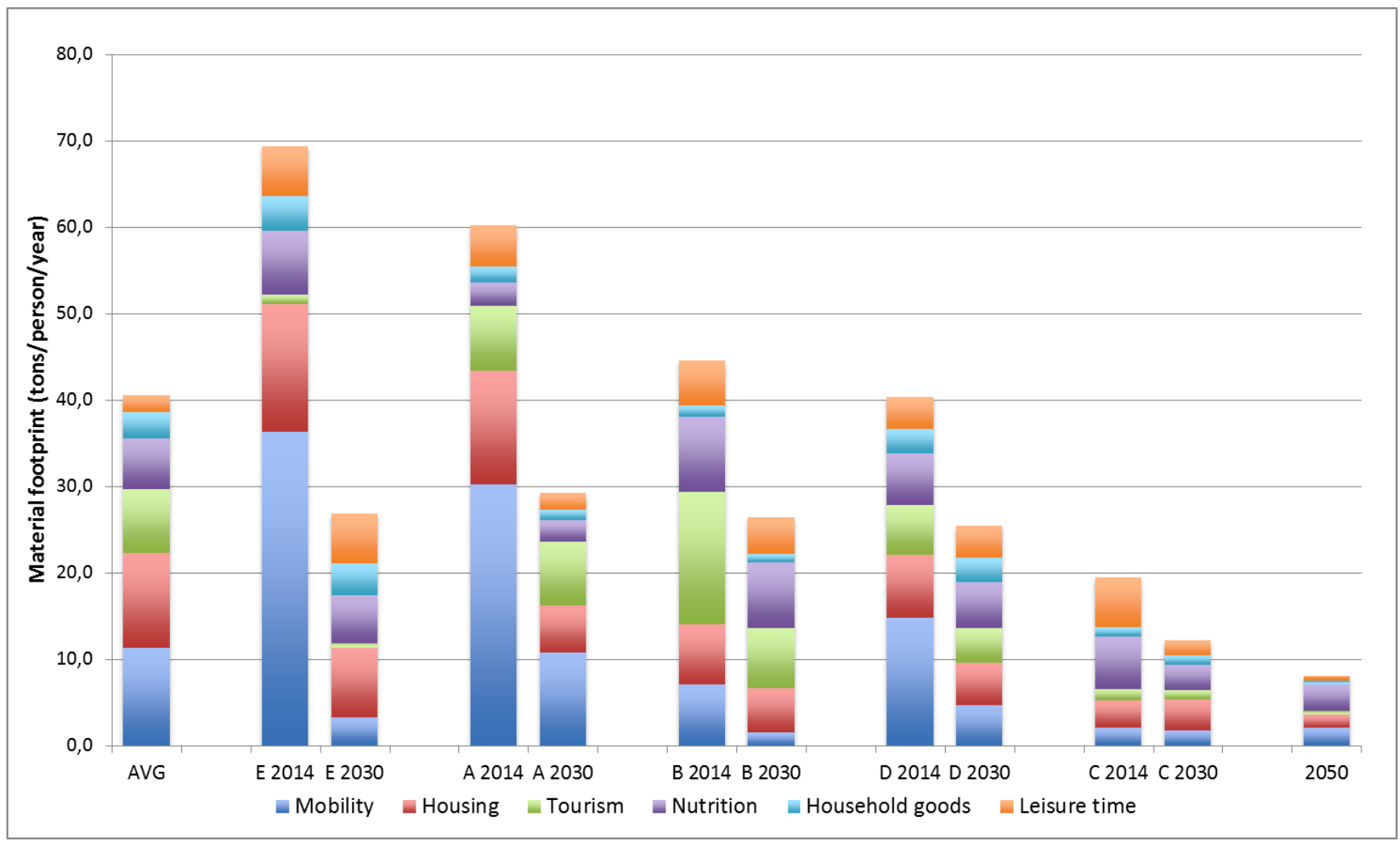

Figure 2. Material footprints of the household at the starting point and the target levels for 2030. The material footprint of an average Finn is presented on the left and target level of eight tonnes per person per year on the right.

When we sent to households their material footprint results, most of them were surprised of the share of housing and mobility. On the basis of this observation, it was useful for households to receive their results in advance, as they had an opportunity to focus on the consumption components with the highest reduction potential when developing ideas for roadmaps. Kotakorpi et al. (2008) found that material footprints were an understandable way for illustrating the impacts of consumption, and this is in line with our findings.

"I started to like this MIPS method because it is so concrete. I had no idea that we, our family, are so far from the sustainable level, and it was very concrete. -- We are such environmental criminals!" (Household E)

As can be seen in Figure 2, households aimed at halving their material footprints in their individual roadmaps. However, during the one-month experiment period all these reductions were not possible to achieve (like energy renovations on the basis of consulting). The households also faced some challenges during the experiment period: Household A had problems with finding public transportation connections due to varying working hours and household $\mathrm{D}$ had some atypical days, which made planning of mobility difficult. Household $\mathrm{C}$ moved to a new house in the beginning of the one-month period and it took time. On the other hand, they felt that the possibility to use car-sharing made going to hardware store easier and more frequent. Therefore, using the car-sharing service temporarily raised their material footprint of mobility compared to the survey period when they used mostly bicycles (see Table 2). 
However, all household succeeded in dropping their material footprints considerably towards their roadmap targets during the experiment period. Significant absolute reductions in material footprints were made in different consumption components, as can be seen in Table 2. Mobility contributed most to the material footprint reduction in most cases. Tourism is not mentioned in Table 2 because during the experiment period no significant observations were made in the field of tourism.

Table 2. Material footprints of households at the starting point, their targets and achieved reductions during the experiments (tonnes per person per year).

\begin{tabular}{|c|c|c|ccccc|c|}
\hline $\begin{array}{c}\text { House- } \\
\text { hold }\end{array}$ & $\begin{array}{c}\text { Starting } \\
\text { Point }\end{array}$ & $\begin{array}{c}\text { Roadmap } \\
\text { target 2030 }\end{array}$ & \multicolumn{2}{|c|}{$\begin{array}{c}\text { Effect of experiments by consumption component } \\
\text { Everyday }\end{array}$} & Nutrition & Housing & Experiment \\
mobility & Household & Leisure & goods & time & result \\
\hline A & $\mathbf{6 0 0 0 0}$ & $\mathbf{2 9 2 0 0}$ & -12000 & -600 & -3300 & -630 & -2300 & $\mathbf{3 9 2 0 0}$ \\
B & $\mathbf{4 4 5 0 0}$ & $\mathbf{2 6 4 0 0}$ & -6300 & -1000 & -1900 & -2100 & -670 & $\mathbf{3 2 5 0 0}$ \\
C & $\mathbf{1 9 4 0 0}$ & $\mathbf{1 2 1 0 0}$ & +1000 & -3400 & -2900 & & & $\mathbf{1 4 7 0 0}$ \\
D & $\mathbf{4 0 3 0 0}$ & $\mathbf{2 5 4 0 0}$ & -5700 & -2600 & -2500 & & & $\mathbf{2 9 4 0 0}$ \\
E & $\mathbf{6 9 3 0 0}$ & $\mathbf{2 6 8 0 0}$ & -26700 & -3500 & -6700 & -400 & & $\mathbf{3 1 7 0 0}$ \\
\hline
\end{tabular}

From households' perspective the experiments succeeded well, all in all, and households mostly felt they had managed to change their everyday routines to be more sustainable. The households thought that they were going to continue some of the experiments, like using local buses, ordering homedelivery of food, and eating vegetarian meals. In other words, we can say that re-routinization happened at least in those areas of consumption where permanent behavioural changes were possible.

When it comes to learning, the households considered the support and knowledge from the experts helpful, especially in the areas of nutrition and energy solutions. Households shared their experiences with their colleagues, friends, and relatives and felt that they had acted as a positive example in their circle of acquaintances. They also told about these experiences to the participants at the final workshop. In other words, households passed on what they had learned during the project both horizontally and vertically.

"The focus on households was important to me in this project. It made these big things, which before this were too large to handle also for us, more human-sized." (Household D)

The households could not predict whether the results from their experiments will have effect on a larger scale. They estimated, however, that their experiences make it easier especially for other households to understand the importance of their consumption behavior, as well as the need for new, more sustainable products and services.

The gatekeepers we interviewed had similar thoughts about the results of the project. The public service providers estimated that the project does have an upscaling potential, as there were representatives from different sectors at the final workshop who can take the results and discussions onwards. They all mentioned that the culture of experimenting is something that is needed in both supply and demand sides. The two private service providers highlighted the importance of acknowledging also the economic aspects of sustainable innovations and thought that gaining the 
'critical mass' of consumers is one of the key elements in upscaling the results. All three of the local policy-makers estimated that the greatest value of the project was the concrete nature of the experiments and examples provided by the participated households. They highlighted that it is important to take all the different actors into account in policy-making.

"If these kind of experiments are not done, how can we know whether the new practices work or not? This way we get real feedback from users and we can identify the shortcomings in time. -- Experiments provide new kind of realism in developing new service models." (Gatekeeper 3)

"I believe that these examples the households have brought up, they make people to think about their own behavior. -- From my opinion, these changes start from the dialogue between different actors and these results can be brought up during this dialogue." (Gatekeeper 7)

All of the gatekeepers interviewed brought up the idea that the results can be exploited, one way or another, in the development of the new residential area in Jyväskylä. Examples of this utilization include further testing of car-sharing services, common spaces in housing, and further implementation of the culture of experimentation in local decision-making.

\section{Conclusions and outlook}

In this paper, we have developed HST, a transdisciplinary methodology for improving Household-level Sustainability Transitions to achieve an absolute reduction in the resource use of household consumption. The HST methodology broadens the view from material footprint assessment to the whole Transition-Enabling Cycle. Households were engaged in the study not only by reporting about their consumption but also by participating in roadmapping, testing, and co-operating with local actors in order to facilitate upscaling. The new HST methodology goes beyond previous studies that focused on measuring footprints and identifying potentials for the absolute reduction of resource use. With the HST methodology households established their own roadmaps towards sustainable resource use. During the one-month experiment period, the households tested relevant options for an absolute reduction of their material footprints towards their personal target levels.

The Transition-Enabling Cycle provided a useful framework for developing the HST methodology and studying the new practices for achieving absolute reduction in material resource use. By doing experiments in households' everyday lives, the implementation of absolute reduction becomes real and measurable. Since the material footprint can be used to measure all aspects of consumption, it helps to keep the data produced understandable and manageable throughout the research process. This can be seen as strength when going through the whole transition process together with households and other actors.

The results show that achieving a significant absolute reduction in the material footprint of consumption is possible by making relatively few changes in the consumption practices of households. The results also show, however, that achieving these remarkable absolute reductions requires cooperation between end-users and product and service suppliers, as services like on-demand buses or

car-sharing are not yet available on a wider scale. This co-operation becomes even more vital when the target is an absolute reduction to the sustainable level of eight tonnes of material resources per person 
per year. The encouraging result is that we do not have to wait until 2030 to be on the mid-point towards sustainable lifestyles but that point can be achieved even today (see household $\mathrm{E}$ in Table 2).

The small number of households made the in-depth nature of the study possible, and gave us new information on dynamics of everyday living and re-routinization of new practices. The observation of households gave us information on the successes and failures of more sustainable practices, and the reasons behind these successes and failures. This way, both scientific knowledge and user perspectives can be better used together to induce the sustainability transition and the absolute reduction in resource use so that the gap between macro strategies on sustainability and micro implementation in everyday life, as described by Liedtke et al. (2013) can be bridged.

It would be interesting to observe the development of the new routines in households and the upscaling of the results from the project at local level in the longer run. Due to the several projects conducted in Jyväskylä (e.g. Mattinen et al., 2014), of which the Future Household project was one, the City of Jyväskylä has pledged its support to sustainable development and 'resource wisdom' of the area. Hence, we can say that our aim to facilitate sustainability transition by experiments at the niche level may lead to developing options for mainstreaming more sustainable services, products, and infrastructure for the broader public, or in other words, socio-technical transitions at the local level. This can make absolute reduction in resource use reality on a much broader level than the specific households that participated in the project.

In the context of the Future Household project, with a small number of households and a surrounding already interested in solutions for the absolute reduction of resource use, the first application of the HST methodology succeeded well. However, five households in one city will not yet change the world. For the generalizations of the Household-level Sustainability Transition approach and the results of its first application, more projects and studies on household consumption need to be conducted. It would also be crucial to broaden the studies to include citizens that are not as aware of the challenges of sustainability as the participants in this study, as we can assume that the barriers they face might be different. Therefore, efforts should be spent on upscaling the HST approach to a much broader context and public. This could include IT-based approaches for consumption monitoring, material footprint calculation, and even roadmapping, testing and upscaling. Also service-providers like the ones participating in the experimenting period should be linked to this broader application of HST. We hope to inspire other researchers, as well as local actors, in different countries to establish similar projects in order to speed up the transition to sustainable consumption, as well as the absolute reductions in natural resource use.

\section{Acknowledgements}

The authors would like to thank the three anonymous reviewers for their in-depth comments and constructive suggestions, which helped to improve the quality of the article considerably. In addition, the authors would like to thank the Finnish Innovation Fund Sitra for funding the project 'Future Household' during which the study was conducted. Senja Laakso would like to acknowledge the financial support of the University of Helsinki doctoral programme in interdisciplinary environmental sciences (DENVI). Michael Lettenmeier would like to acknowledge the financial support of the project 'Socio-economic practices of sustainable development in the new industrialization' founded by the Government of the Russian Federation, Grant 074-U01 and conducted within the ITMO Univ. St. Petersburg. 


\section{Conflict of interest}

The authors declare no conflict of interest.

\section{References}

Aachener Stiftung Kathy Beys, 2011. Factsheet Measuring Resource Extraction. Sustainable Resource Management Needs to Consider Both Used and Unused Extraction. Aachener Stiftung Kathy Beys, Aachen, Germany.

Ayres, R.U., Knees, A.V., 1969. Production, Consumption, and Externalities. Am. Econ. Rev. 59, 282 297.

Barr, S., 2006. Environmental Action in the Home: Investigating the 'Value-Action' Gap. Geography $91,1,43-54$.

Bringezu, S., 2009. Visions of a sustainable resource use, in: Bringezu, S., Bleischwitz, R., (Eds.), Sustainable Resource Management. Global Trends, Visions and Policies, Greenleaf, Sheffield, pp. $155-215$.

Bringezu, S., Schütz, H., Moll, S., 2003. Rationale for and Interpretation of Economy-Wide Materials Flow Analysis and Derived Indicators. J. Ind. Ecol. 7, 2, 43-64.

Bringezu, S., Schütz, H., Saurat, M., Moll, S., Acosta-Fernández, J., Steger, S., 2009. Europe’s

Resource Use. Basic Trends, Global and Sectoral Patterns and Environmental and Socioeconomic Impacts, in: Bringezu, S., Bleischwitz, R., (Eds.), Sustainable Resource Management. Global Trends, Visions and Policies, Greenleaf, Sheffield, pp. 52-154.

Bringezu, S., 2011. Key Elements for Economy-wide Sustainable Resource Management. Responsab. and Environ. 61, 78-87. Available at: http://annales.org/re/2011/re-janvier-2011/BRINGEZU.pdf

Caeiro, S., Ramos, T.B., Huisingh, D., 2012. Procedures and criteria to develop and evaluate household sustainable consumption indicators. J. of Clean. Prod. 27, 72-91.

Doyle, R., Davies, A.R., 2013. Towards sustainable household consumption: exploring a practice oriented, participatory backcasting approach for sustainable home heating practices in Ireland. J. Clean. Prod. 48, 260-271.

Erdmann, L., Graedel, T.E., 2011. Criticality of non-fuel minerals: a review of major approaches and analyses. Environ. Sci. and Technol. 45, 18, 7620-7630.

Geels, F.W., 2002. Technological transitions as evolutionary reconfiguration processes: a multi-level perspective and a case- study. Res. Policy 31, 1257-1274.

Geels, F.W., 2011. The multi-level perspective on sustainability transitions: Responses to seven criticisms. Environ. Innov. Soc. Transitions, 1, 24-40.

Giljum, S., Hinterberger, F., Bruckner, M., et al., 2009. Overconsumption? Our use of the world's natural resources. SERI, GLOBAL 2000, Friends of the Earth Europe. Available at: http://www.foe.co.uk/sites/default/files/downloads/overconsumption.pdf 
Global Footprint Network, 19.8.2014. August 19th is Earth Overshoot Day: The date our Ecological Footprint exceeds our planet's annual budget. Press release. Available at: http://www.footprintnetwork.org/images/article_uploads/EarthOvershootDay_2014_PR_General.pdf

Groezinger, R., Verbree, R., Hicks, C., Ritola, M., 2013. Scenarios for sustainable lifestyles. Pathways toward a positive future, Ökom: Ökologisches Wirtschaften, Munich, 28, 3, 41-46.

Halada, K., Shimada, M., Ijima, K., 2008. Forecasting of the Consumption of Metals up to 2050. Mater. Trans. 49, 3, 402-410.

Heiskanen, E., Johnson, M., Vadovics, E., 2013. Learning about and involving users in energy saving on the local level. J. Clean. Prod. 48, 241-249.

Hirvilammi, T., Laakso, S., Lettenmeier, M., Lähteenoja, S., 2013. Studying Well-being and its Environmental Impacts: A Case Study of Minimum Income Receivers in Finland. J. Hum. Dev. Capab. $14,1,134-154$.

Hobson, K., 2002. Competing Discourses of Sustainable Consumption: Does the 'Rationalisation of Lifestyles' Make Sense? Env. Polit. 11, 2, 95-120.

Kemp, R., Schot, J., Hoogma, R., 1998. Regime shifts to sustainability through processes of niche formation: the approach of strategic niche management. Technol. Anal. Strateg. Manag. 10, 175-196.

Kersten, W.C., Crul, M.R.M., Geelen, D.V., Meijer, S.A., Franken, V., 2014. Engaging beneficiaries of sustainable renovation - Exploration of design-led participatory approaches. J. of Clean. Prod. Available online.

Kopsakangas-Savolainen, M., Juutinen, A., 2013. Energy consumption and savings: A survey-based study of Finnish households, J. Environ. Econ. Policy, 2, 1, 71-92.

Kotakorpi, E., Lähteenoja, S., Lettenmeier, M., 2008. Household MIPS. Natural resource consumption of Finnish households and its reduction. The Finnish Environment 43en. Ministry of the Environment, Environmental Protection Dep.

Krausmann, F., Gingrich, S., Eisenmenger, N., et al., 2009. Growth in global materials use, GDP and population during the 20th century. Ecol. Econ. 68, 10, 2696-2705.

Kuittinen, O., Mokka, R., Neuvonen, A., 2013. iFuture - The Diversity of Sustainable Lifestyles. People's forum workshop summaries. Available at http://www.sustainablelifestyles.eu/fileadmin/images/content/D7.3_iFuture_report.pdf

Laakso, S., 2011. Onko elämä perusturvan varassa kestävää? Ympäristövara ekologisesti ja sosiaalisesti kestävän kulutuksen tarkastelussa. (Is Life on Basic Social Security Sustainable? Environmental Space as a Framework for Studying Ecologically and Socially Sustainable Consumption. In Finnish). Master's Thesis. Univ. of Helsinki, Dep. of Environ. Sci. Helsinki. 
Lähteenoja, S., Neuvonen, A., Groezinger, R., 2013. From Global Champions to Local Loops:

Sustainable Lifestyles in Europe 2050. Conference paper presented in World Resources Forum 2013, Davos. Available at http://www.demoshelsinki.fi/julkaisut/from-global-champions-to-local-loopssustainable-lifestyles-in-europe-2050/

Leppänen, J., Neuvonen, A., Ritola, M., et al., 2012. Scenarios for Sustainable Lifestyles 2050: From Global Champions to Local Loops. Future Scenarios for New European Social Models with Visualisations. Available at http:// www.sustainablelifestyles.eu/fileadmin/images/content/D4.1_FourFutureScenarios.pdf

Lettenmeier, M., Hirvilammi, T., Laakso, S., Lähteenoja, S., Aalto, K., 2012. Material Footprint of Low-Income Households in Finland - Consequences for the Sustainability Debate. Sustainability. 4, 7, 1426-1447.

Lettenmeier, M., Lähteenoja, S., Hirvilammi, T. Laakso, S., 2014a. Resource consumption of lowincome households - approach for defining a decent lifestyle? Sci. Total Environ. 481, 681-684.

Lettenmeier, M., Liedtke, C., Rohn, H., 2014b. Eight Tonnes of Material Footprint - Suggestion for a Resource Cap for Household Consumption in Finland. Resources 3, 488-515.

Lettenmeier, M., Rohn, H., Liedtke, C., Schmidt-Bleek, F., 2009. Resource Productivity in 7 steps. How to Develop Eco-innovative Products and Services and Improve Their Material Footprint. Wuppertal Spezial 41 Wuppertal Inst. for Climate, Environment and Energy, Wuppertal.

Liedtke, C., Buhl, J., Ameli, N., 2013. Microfoundations for Sustainable Growth with Eco-Intelligent Product Service-Arrangements. Sustainability, 5, 1141-1160.

Loorbach, D., 2007. Transition management: New mode of governance for sustainable development. International Books, Utrecht, the Netherlands.

Loorbach, D., Rotmans, J., 2006. Managing transitions for sustainable development, in: Wieczorek, A.J., Olshoorn, X., (Eds.), Understanding Industrial Transformation: Views from Different Disciplines. Environment \& Policy, 44, Springer Netherlands, pp. 187-206.

Loorbach, D., Rotmans, J., 2010. The practice of transition management: Examples and lessons from four distinct cases. Futures 42, 237-246.

Lorek, S., Spangenberg, J.H., 2001 Indicators for environmentally sustainable household consumption', Int. J. Sustain. Dev. 4, 1, 101-120.

Lutz, C., Lehr, U., Wiebe, K.S., 2012. Economic effects of peak oil. Energy Policy, 48, 829-834.

Lyytimäki, J., Tapio, P., Varho, V., Söderman, T., 2013. The use, non-use and misuse of indicators in sustainability assessment and communication. Int. J. Sustain. Dev. and World Ecol. 20, 5, 385-393. 
Mattinen, M., Antikainen, R., Salo M., 2014. Jyväskylän resurssiviisaiden kokeilujen vaikutusarviointi sekä laajenemisvaikutukset (Impact assessment of resource-wise trials in the Jyväskylä region. In Finnish). Sitra Studies 75. Helsinki.

Mäenpää, I., 2005. Kansantalouden ainevirtatilinpito. Laskentamenetelmät ja käsitteet. Suomen ainetaseet 1999 (National material flow accounting. Calculation methods and glossary. Finnish material balance 1999. In Finnish). Edita Prima Oy, Helsinki.

Mont, O., Neuvonen, A., Lähteenoja, S., 2014. Sustainable lifestyles 2050: stakeholder visions, emerging practices and future research. J. Clean. Prod. 63, 24-32.

Neuvonen, A., Kaskinen, T., Leppänen, J., Lähteenoja, S., Mokka, R., Ritola, M., 2014. Lifestyles backcasting as an agency-orientated method for creating sustainable futures. Futures, 58, 66-76.

Rip, A., Kemp, R., 1998. Technological change, in: Rayner, S., Malone, E.L. (Eds.), Human Choice and Climate Change, vol. 2. Battelle Press, Columbus, OH, pp. 327-399.

Ritthoff, M., Rohn, H., Liedtke, C., 2002. Calculating MIPS - Resource Productivity of Products and Services, first ed. Wuppertal Spezial 27e. Wuppertal Inst. for Climate, Environment and Energy. Wuppertal.

Rotmans, J., Loorbach, D., 2009. Complexity and Transition Management. J. Ind. Ecol. 13, 2, 184-196.

Rotmans, J., Kemp, R., van Asselt, M., 2001. More evolution than revolution: Transition management in public policy. Foresight 3, 1, 15-31.

Schmidt-Bleek, F., 1993. Wieviel Umwelt braucht der Mensch? MIPS - das Maß für ökologisches Wirtschaften, first ed. Birkhäuser, Berlin.

Schmidt-Bleek, F., 2009. The Earth: Natural Resources and Human Intervention, first ed. Haus Publishing, London.

Schmidt-Bleek, F. et al., 1998. MAIA Einführung in die Material-Intensitäts-Analyse nach dem MIPS Konzept, first ed. Birkhäuser, Basel.

Schneidewind, U., Augenstein, K., 2012. Analyzing a transition to a sustainability-oriented science system in Germany. Environ. Innov. Soc. Transitions, 3, 16-28.

Schneidewind, U., Scheck, H., 2012. Zur Transformation des Energiesektors : ein Blick aus der Perspektive der Transition-Forschung, in: Servatius, H.-G., Schneidewind, U., Rohlfing, D. (Hrsg.) Smart Energy - Wandel zu einem nachhaltigen Energiesystem. Springer, Heidelberg, pp. 45-61.

Schot, J.W., Geels, F.W., 2008. Strategic niche management and sustainable innovation journeys: theory, findings, research agenda and policy. Technol. Anal. Strateg. Manag. 20, 537-554.

Schroeder, R., 2010. The Limits to Transforming the Environment and the Limits to Sociological Knowledge. Sustainability, 2, 8, 2483-2498. 
Seppälä, J., Mäenpää, I., Koskela, S., et al., 2011. An Assessment of Greenhouse Gas Emissions and Material Flows Caused by the Finnish Economy Using the ENVIMAT Model. J. Clean. Prod. 19, 16, $1833-41$.

Shove, E., Walker, G., 2010. Governing transitions in the sustainability of everyday life. Res. Policy 39, 471-476.

Smith, A., Stirling, A., Berkhout, F., 2005. The governance of sustainable socio-technical transitions. Res. Policy 34, 1491-1510.

Spaargaren, G., 1997. The Ecological Modernization of Production and Consumption, Landbouw Universiteit Wageningen.

Statistics Finland, 2010. Tulot ja kulutus, tulonjakotilasto 2010 (Income and consumption, income distribution statistics 2010. In Finnish). https://www.stat.fi/til/tjt/2010/tjt_2010_2012-05-23_fi.pdf. Accessed 29.5.2014.

Stricks, V., Hinterberger, F., Moussa, J., 2014. Developing targets for global resource use. Input paper for the expert workshop on targets for material use (Berlin, 12th Janurary 2015). IntRESS Working Paper 2.3. Sustainable Europe Research Institute, Vienna, Austria.

Tukker, A., Cohen, M.J., Hubacek, K., Mont, O., 2010. The Impacts of Household Consumption and Options for Change. J. Ind. Ecol. 14, 1, 13-30.

United Nations, 1992. "Earth Summit: Agenda 21 the United Nations programme of action for sustainable development." In United Nations Conference on Environment and Development (UNCED), 3-14.6.1992. Department of Public Information, New York, USA, Rio de Janeiro, Brazil.

WWF, 2012. Living Planet Report 2012. Biodiversity, biocapacity and better choices. Available at http://awsassets.panda.org/downloads/1_lpr_2012_online_full_size_single_pages_final_120516.pdf 